\title{
Development and Validation of Stability Indicating HPTLC Assay for Determination of Gemifloxacin Mesylate in Dosage Forms
}

\author{
Ashraf M. Mahmoud1,2*, Noha N. Atia1, Salwa R. El-Shabouri' ${ }^{1}$, Wesam M. El-Koussi1 \\ ${ }^{1}$ Department of Pharmaceutical Analytical Chemistry, Faculty of Pharmacy, Assiut University, Assiut, Egypt \\ ${ }^{2}$ Department of Pharmaceutical Chemistry, College of Pharmacy, Najran University, Najran, KSA \\ Email: ${ }^{*}$ a.mahmoud2007@yahoo.com
}

Received 4 December 2014; accepted 8 January 2015; published 16 January 2015

Copyright (C) 2015 by authors and Scientific Research Publishing Inc.

This work is licensed under the Creative Commons Attribution International License (CC BY). http://creativecommons.org/licenses/by/4.0/

cc) (i) Open Access

\begin{abstract}
Simple and sensitive stability-indicating high performance thin layer chromatography (HPTLC) assay was developed and validated for quantitative determination of the antibacterial drug, gemifloxacin mesylate (GFX) in presence of its degradation products and ambroxol hydrochloride. The chromatographic separation was performed on HPTLC precoated silica gel plate ${ }^{20 F_{254}}$ as stationary phase. The mobile phase consisted of a mixture of ethyl acetate: methanol: $25 \%$ ammonia, $(8: 4.5: 3, \mathrm{v} / \mathrm{v} / \mathrm{v})$. The detection was performed using fluorescence mode and the emission intensity was measured using optical filter $\mathrm{K} 400$ after excitation at $342 \mathrm{~nm}$. The $R_{\mathrm{f}}$ value for GFX was $0.47 \pm$ 0.03. Good correlation coefficient was obtained over the concentration range of $1.5-180 \mathrm{ng} / \mathrm{band}$. The LOD and LOQ of the proposed method were 0.28 and $0.86 \mathrm{ng} / \mathrm{band}$, respectively. The proposed method was successfully applied for the analysis of GFX in its single and combined dosage forms. Moreover, it was utilized to investigate the kinetics of acidic, alkaline, neutral, oxidative and photolytic degradation of the drug. The apparent kinetic-order rate constants and half-life times of the degradation process were calculated. Furthermore, the proposed method was successfully applied for investigating the factors affecting the storage of GFX.
\end{abstract}

\section{Keywords}

HPTLC, Gemifloxacin Mesylate, Stability Indicating Assay, Kinetics, Degradation, Pharmaceutical Preparations

\footnotetext{
${ }^{*}$ Corresponding author.
}

How to cite this paper: Mahmoud, A.M., Atia, N.N., El-Shabouri, S.R. and El-Koussi, W.M. (2015) Development and Validation of Stability Indicating HPTLC Assay for Determination of Gemifloxacin Mesylate in Dosage Forms. American Journal of Analytical Chemistry, 6, 85-97. http://dx.doi.org/10.4236/ajac.2015.62008 


\section{Introduction}

The inherent stability characteristics of a drug should be established using stress studies on the parent drug according to the stability test ICH guideline Q1A (R2) [1]. Besides, the intrinsic stability and kinetic studies are the fundamental elements in the search for possible degradation products of drugs; however, these products do not commonly appear under normal drug storage conditions. High performance thin-layer chromatography (HPTLC) has been widely used in the pharmaceutical analysis as stability-indicating assay [2], and for clinical pharmacokinetic studies [3]. The analysis in these areas usually involves measurement of very low concentrations of drugs and/or degradation products which can be detected by HPTLC in nanogram and picogram levels in absorbance and fluorescence based measurements, respectively. The importance and widespread of HPTLC in pharmaceutical analysis are attributed to their inherent selectivity, high sensitivity, sustainability and low operating costs. Moreover, its use in the developing countries will greatly help them in identifying the counterfeit and sub-standard pharmaceutical products in their markets, where the WHO has identified this illegal distribution as a major problem in the developing countries [4].

Gemifloxacin mesylate (GFX, Figure 1) is a recently developed fluoroquinolone antibacterial compound with a broad spectrum activity. It acts through the formation of a ternary complex with both DNA gyrase and topoisomerase IV which are responsible for the blockade of DNA replication and transcription [5] [6]. Thus, it has an excellent in vitro and in vivo efficacy with good pharmacokinetic profile [7]. Nowadays, GFX is commonly used for treatment of community acquired pneumonia and acute bacterial exacerbation of chronic bronchitis that provide high rates of mortality worldwide [7].

GFX is not yet the subject of a monograph in any pharmacopoeia. Reviewing the literature revealed that, several analytical methods were reported for determination of GFX in its pharmaceutical preparations or human plasma by spectrofluorometrically [8], LC-MS-MS [9], HPLC [10] and HPTLC [11]-[13]. But, the literature is still lacking the analytical procedures based on kinetic study that describe the stability of GFX under different stress conditions. Whereas, most of the reported stability indicating assays [13]-[18] did not provide a complete discussion about the behavior of GFX at different time intervals. Moreover, the kinetic studies of GFX were restricted on one method that describes the kinetic of GFX after its photo-degradation only [19].

Therefore, the aim of the present study is the development of the first stability-indicating HPTLC assay using fluorescence detection for determination of GFX in dosage forms. In addition, it used for studying the inherent stability of GFX under different stress conditions according to ICH guidelines [1]. The present study also includes the investigation of degradation kinetics and the kinetics run parameters under different degradation stress conditions. Moreover, different factors that affect the stability of GFX have been studied.

\section{Experimental}

\subsection{Materials}

Analytically pure GFX (99.8\%) was provided from Tabuk Pharmaceutical Manufacturing Co., KSA and used as received without further purifications. Ambroxol HCl (AMB) was obtained from Galaxo Wellcome, S.A.E., El Salam City, Cairo, Egypt. The pharmaceutical dosage forms used in this study were; Factive ${ }^{\circledR}$ (Oscient Pharmaceuticals, USA), Floxguard ${ }^{\circledR}$ (Advocure Pharmaceuticals, Obour city, Egypt), Quinabiotic ${ }^{\circledR}$ (Medizen Pharmaceutical Industries, Alexandria, Egypt), Gemique ${ }^{\circledR}$ (Meivo International for Pharmaceutical Indusries, Alexandria, Egypt) and Gemiloxes ${ }^{\circledR}$ (Sabaa International Company for Pharmaceuticals and Chemicals, Egypt) which are labeled to contain an equivalent amount of $320 \mathrm{mg}$ of gemifloxacin per tablet. Synthetic mixture was pre-

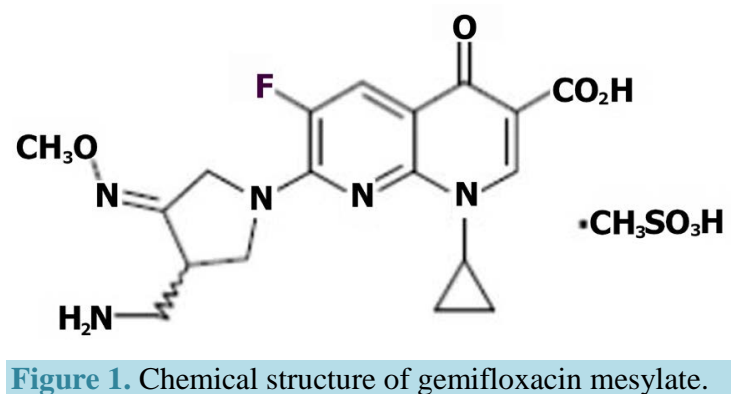


pared according to the dosage form "G-CIN-A" in India (Hetero Pvt. Ltd, India) which are labeled to contain $320 \mathrm{mg}$ of GFX and $75 \mathrm{mg}$ of ambroxol $\mathrm{HCl}$ per tablet. HPLC grade methanol was purchased from Sigma Aldrich, Seelze, Germany. Hydrogen peroxide $(30 \% \mathrm{v} / \mathrm{v})$ was obtained from Arabic Laboratory Equipment Co., Egypt. Other solvents and materials used throughout this study were of analytical grade.

\subsection{Instrumentation and Chromatographic Conditions}

The sample was applied with Camag microliter syringe on HPTLC precoated silica gel plate $60 \mathrm{~F}_{254}(20 \times 5 \mathrm{~cm}$, 6 - $8 \mu \mathrm{m}$ thicknesses; Merck, Darmstadt, Germany) by using Camag Linomat V applicator (Camag, Switzerland, Germany). The sample was sprayed in the form of narrow bands of $4 \mathrm{~mm}$ length at a constant rate $3 \mu \mathrm{l} / \mathrm{s}$. Mobile phase consisted of ethyl acetate: methanol: $25 \%$ ammonia $(8: 4.5: 3 \mathrm{v} / \mathrm{v} / \mathrm{v})$ was freshly prepared and used for the development step. Linear ascending development was carried out in trough glass chamber $(24 \mathrm{~cm} \mathrm{~W} \times 14 \mathrm{~cm} \mathrm{H}$ $\times 9.5 \mathrm{~cm} \mathrm{D}$, standard type) (Sigma-Aldrich Co., USA) that pre-saturated with the mobile phase for at least 20 min at room temperature $\left(25^{\circ} \mathrm{C} \pm 2^{\circ} \mathrm{C}\right)$. The solvent front was moved about three-fourths of the length of the plate. After that, the plate was air-dried for about 5 min. The densitometric scanning was performed by using Camag TLC scanner III system equipped with Hg lamp for the fluorescence detection. Where, the scanning was performed using optical filter K400 after excitation at $342 \mathrm{~nm}$. The system control and data acquisition were performed by winCATS software, version 1.4.4.6337. Quantitative evaluations were performed via peak areas. UV lamp (Vilber Lournate 220 V 50 Hz; Marne-lavallee Cedex, France) and MLV type thermostatically controlled water bath (Salvis AG Emmenbruck, Luzern, Germany) were used for the photo and aqueous degradation of GFX, respectively.

\subsection{Preparation of Standard Solutions}

A stock solution containing $100 \mu \mathrm{g} / \mathrm{ml}$ of GFX was prepared in methanol. This solution was further diluted with the same solvent to obtain a working standard solutions containing $0.5-60 \mu \mathrm{g} / \mathrm{ml}$ of GFX. The solutions were kept in the refrigerator and protected from light.

\subsection{Procedure for Pharmaceutical Formulations}

\subsubsection{Tablets Sample Solution}

Twenty tablets were weighed and finely powdered. An accurately weighed amount of the powder equivalent to $25 \mathrm{mg}$ of GFX was transferred into a $100 \mathrm{ml}$ calibrated flask, and dissolved in about $40 \mathrm{ml}$ methanol. The contents of the flask were swirled, sonicated for $5 \mathrm{~min}$, and then completed to volume with methanol. The contents were mixed well and filtered rejecting the first portion of the filtrate. Further dilution was made with methanol to obtain sample solution containing $40 \mu \mathrm{g} / \mathrm{ml}$ as a suitable concentration for the analysis.

\subsubsection{Synthetic Mixture Preparation}

An accurately weighed amount of the powder equivalent to $32 \mathrm{mg}$ of GFX and $7.5 \mathrm{mg}$ AMB (i.e. in the ratio of 4.3:1.0 w/w as in the combined dosage form) were transferred into a $100 \mathrm{ml}$ calibrated flask. The contents were ultrasonicated for 5 min with $40 \mathrm{ml}$ methanol then, the void volume was completed with the same solvent. After that, further dilution was made with methanol to obtain sample solution containing $60 \mu \mathrm{g} / \mathrm{ml}$ of GFX and 14.06 $\mu \mathrm{g} / \mathrm{ml}$ of $\mathrm{AMB}$ as a suitable concentrations for the analysis.

\subsection{Degradation Studies}

\subsubsection{Acidic Degradation}

Ten milligrams of GFX was transferred into a series of $25 \mathrm{ml}$ volumetric flasks and dissolved in $10 \mathrm{ml} 1 \mathrm{M} \mathrm{HCl}$. The flasks were thoroughly covered with aluminum foil, allowed to stand at room temperature $\left(25^{\circ} \mathrm{C} \pm 2^{\circ} \mathrm{C}\right)$ for $1,2,3,4,6,8,10$ and $12 \mathrm{hr}$, neutralized and completed to volume with methanol. After that, further dilution with methanol was done to produce final concentration of $50 \mu \mathrm{g} / \mathrm{ml}$ and $3 \mu \mathrm{l}$ from these solutions (containing $150 \mathrm{ng} /$ band) corresponding to each time interval was applied in triplicate on HPTLC plate then the general procedure was followed.

\subsubsection{Alkaline Degradation}

The same procedure as acidic hydrolysis was employed using $0.2 \mathrm{M} \mathrm{NaOH}$ instead of $1 \mathrm{M} \mathrm{HCl}$. 


\subsubsection{Oxidative Degradation}

Ten milligrams of GFX was transferred into a series of $10 \mathrm{ml}$ volumetric flasks and dissolved in $10 \mathrm{ml} 30 \%$ hydrogen peroxide. The flasks were thoroughly covered with aluminum foil, allowed to stand at room temperature $\left(25^{\circ} \mathrm{C} \pm 2^{\circ} \mathrm{C}\right)$ for $1,2,3,4,6,8$ and $10 \mathrm{hr}$. Then, further dilution with methanol was done to produce final concentration of $50 \mu \mathrm{g} / \mathrm{ml}$ then the general procedure was followed.

\subsubsection{Neutral (Aqueous) Hydrolysis}

Ten milligrams of GFX was transferred into $10 \mathrm{ml}$ volumetric flask and completed to the mark with double distilled water. The flask was heated in thermostatted water bath at $100^{\circ} \mathrm{C}$ for $12 \mathrm{hr}$ and aliquot was taken at different time intervals (1, 2, 3, 4, 6, 8, 10 and $12 \mathrm{hr}$ ) and further diluted with methanol to produce final concentration of $50 \mu \mathrm{g} / \mathrm{ml}$.

\subsubsection{Photolytic Degradation}

Five milliliters of GFX stock solution $(1 \mathrm{mg} / \mathrm{ml})$ was transferred into a series of matched $1 \mathrm{~cm}$ quartz sample cells. The cells were exposed to UV radiation at a wavelength of $365 \mathrm{~nm}$ and at a distance of $15 \mathrm{~cm}$, placed in a wooden cabinet for different time intervals $(1,2,3,4,6$ and $8 \mathrm{hr})$. After that, $0.5 \mathrm{ml}$ of each solution was transferred into $10 \mathrm{ml}$ volumetric flask and diluted with methanol to produce final concentration of $50 \mu \mathrm{g} / \mathrm{ml}$. Control sample was protected from light with aluminum foil and used at the same concentration and then the general procedure was followed directly.

\subsection{Stability of Standard Solution at Different Storage Conditions}

The stability of GFX (50 $\mathrm{g} / \mathrm{ml})$ in methanol was monitored under four storage conditions; in refrigerator $\left(4^{\circ} \mathrm{C}\right)$, at room temperature $\left(25^{\circ} \mathrm{C} \pm 2^{\circ} \mathrm{C}\right)$ with protection or unprotection (top-bench) from light; or under direct daylight exposure (prepared in transparent tightly capped glass tube and positioned behind closed window glass). The concentration of GFX was monitored under these conditions at different time intervals $(24,48,72,96,120$ and $144 \mathrm{hr}$ ). The change in the concentration of GFX was analyzed against freshly prepared standard solution.

\section{Results and Discussion}

\subsection{Optimization of the Chromatographic Conditions}

\subsubsection{Mobile Phase}

The separation of GFX could be adjusted by changing the composition of the mobile phase. Initially individual solvents like methanol, hexane, chloroform, and ethyl acetate were tested. The results showed that GFX was developed with methanol and ethyl acetate but with unsuitable $R_{f}$ value. Then Different ratios of ethyl acetate and methanol were investigated. The results indicated that the best $\mathrm{R}_{\mathrm{f}}$ value was achieved when the ratio of ethyl acetate: methanol was 8:4.5 (v/v) but tailing was observed. Several experiments have shown that the employment of an appropriate ratio of acid or base in the mobile phase may improve the chromatographic peak resolution [20]. The acidic $\mathrm{pH}$ of the mobile phase was also tested using either acetic or phosphoric acid and was found that they significantly reduce the fluorescence intensity and broaden the chromatographic peak. Thus, the acid was replaced with ammonia solution where different concentrations of ammonia $(10 \%, 15 \%, 20 \%, 25 \%$ or $33 \%$ ) were tested. The results showed that $25 \%$ ammonia was able to improve the shape of the chromatographic peak of GFX and resulting in more symmetric peak. Further experiments were performed and finally the optimum mobile phase was consisted of ethyl acetate: methanol: 25\% ammonia, (8:4.5:3 v/v/v). Figure 2(a), shows a sharp and well-defined symmetrical peak of GFX at $R_{f}=0.47 \pm 0.03$ using the selected mobile phase system.

\subsubsection{Fluorescence Detection}

GFX has a native fluorescence spectrum exhibiting two excitation maxima at 272 and $342 \mathrm{~nm}$ and one emission at $391 \mathrm{~nm}$. The fluorescence intensity obtained at $\lambda_{\mathrm{ex}} 272 \mathrm{~nm}$ was more than that obtained at $\lambda_{\mathrm{ex}} 342 \mathrm{~nm}$. Thus, the first trial was performed by excitation at $272 \mathrm{~nm}$ and optical filter K400 but it was found that the peak of GFX was inverted. This may be due to that the HPTLC plates with fluorescence indicator $\left(\mathrm{F}_{254}\right)$ absorb in wavelength range of 250 - $300 \mathrm{~nm}$, resulting in fluorescence quenching [21]. So, $\lambda_{\mathrm{ex}} 342 \mathrm{~nm}$ and optical filter K400 were selected in this study for direct measurement of the fluorescence intensity of GFX. 


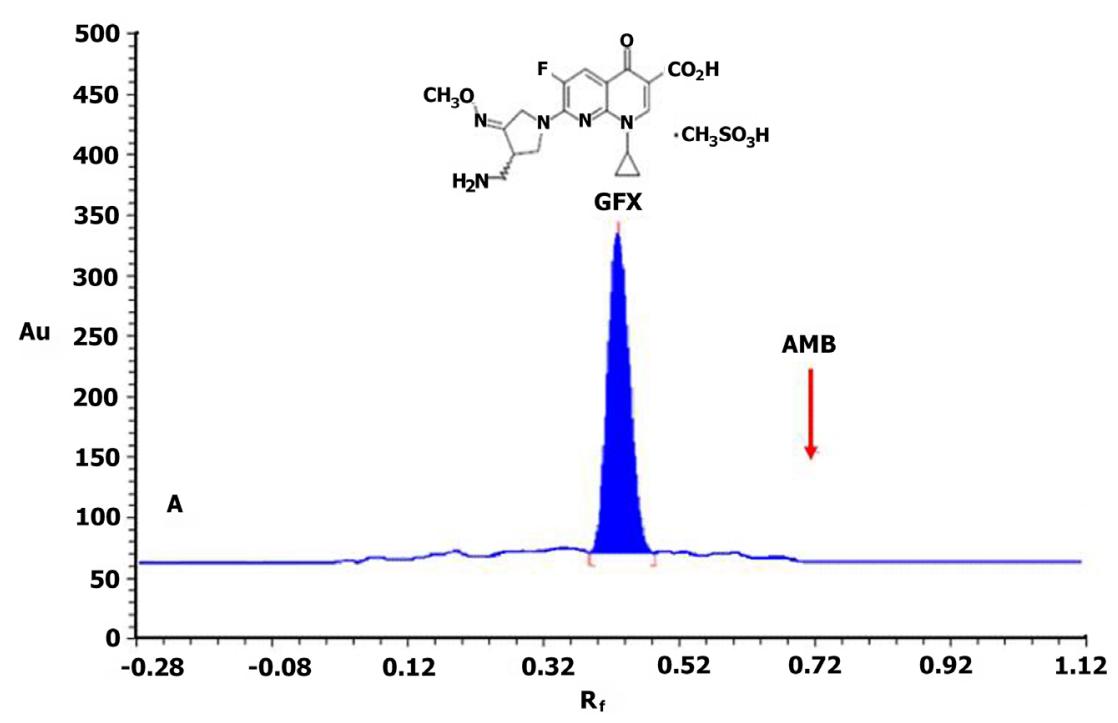

(a)

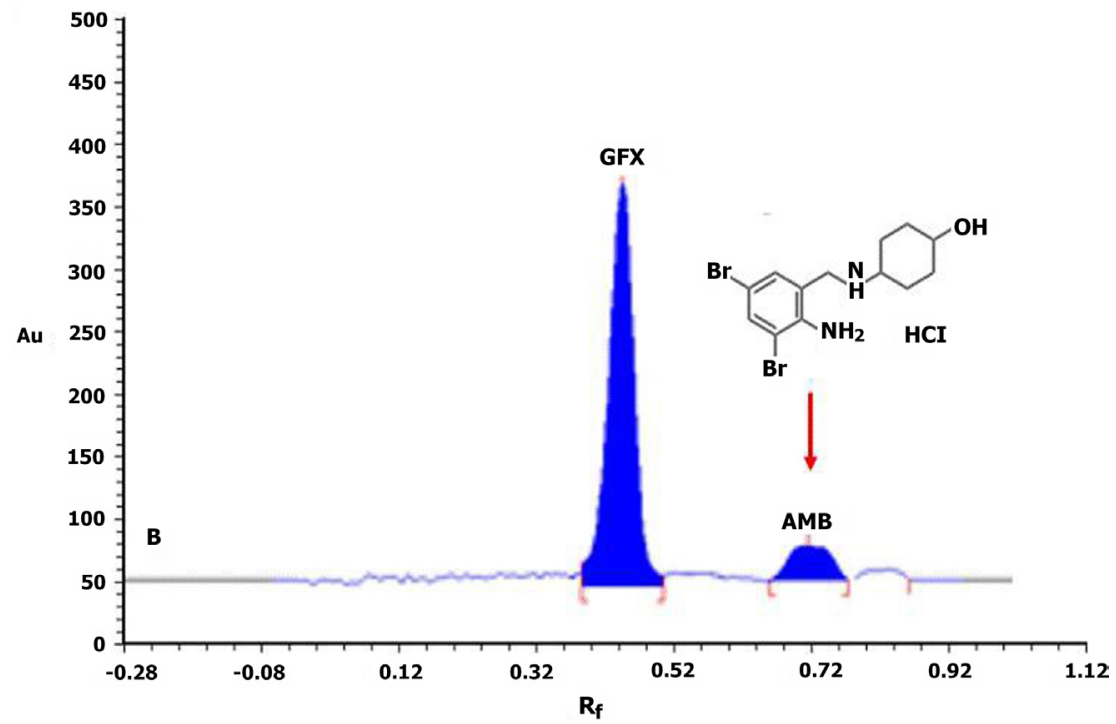

(b)

Figure 2. HPTLC densitograms of GFX (150 ng/band, $\left.\mathrm{R}_{\mathrm{f}} 0.47 \pm 0.03\right)$ and AMB (35 $\mathrm{ng} /$ band, $\mathrm{R}_{\mathrm{f}} 0.72$ ) using: (a) Fluorescence detection by optical filter K400 after excitation at $342 \mathrm{~nm}$; (b) UV detection at $342 \mathrm{~nm}$.

\subsection{Method Validation}

The method was fully validated according ICH guidelines [22]. All results were expressed as percentages, with $\mathrm{n}$ representing the number of values. A $5 \%$ significance level was used for evaluation.

\subsubsection{Linearity, Limits of Detection and Quantitation}

A calibration curve was constructed by plotting the peak area of GFX standard solutions versus different concentrations of GFX. Under the optimum conditions, linear plot $(n=6)$ with good correlation coefficient $(0.9999)$ was obtained over the concentration range $1.5-180 \mathrm{ng} / \mathrm{band}$. The regression equation thus obtained from calibration plots, $\mathrm{y}=82.98 \mathrm{x}+73.46$ (where $\mathrm{y}=$ area obtained, $\mathrm{x}=$ concentration in $\mathrm{ng} / \mathrm{band}$ ), was used for quantitative estimation of GFX in different samples. Where, the mean values of slope and intercept were $82.98 \pm 0.09$ and $73.46 \pm 7.11$, respectively.

The limits of detection (LOD) and quantitation (LOQ) which represents the sensitivity of the proposed me- 
thod were determined [22] using the formula: $\mathrm{LOD}$ or $\mathrm{LOQ}=\kappa \mathrm{SDa} / \mathrm{b}$, where $\kappa$ is a numerical constant equal to 3.3 for LOD and 10 for LOQ, SDa is the standard deviation of the intercept, and $b$ is the slope. The LOD and LOQ values were 0.28 and $0.86 \mathrm{ng} / \mathrm{band}$, respectively which indicated the high sensitivity of the proposed method.

\subsubsection{Accuracy and Precision}

The accuracy of the proposed method was evaluated by determining the percentage recovery of GFX at three different concentrations covering the specified range (six replicates of each concentration). The obtained recovery results shown in Table 1 indicate the high accuracy. In addition, the small \% RSD (0.67\% - 2.66\%) points to the good repeatability of the proposed method.

\subsubsection{Robustness}

Robustness was examined by evaluating the influence of deliberate small variation in the experimental conditions on the performance of the proposed method. It was found that small variation in the mobile phase ratios $( \pm 0.5 \mathrm{ml})$, ammonia concentration $( \pm 5 \%)$ and saturation time $( \pm 5 \mathrm{~min})$ did not significantly affect the results indicating the reliability of the proposed method for the analysis of GFX (Table 2).

\subsubsection{Selectivity}

The selectivity of an assay is a measure of the extent to which the method can be used to determine a particular compound in the matrices analyzed without interference from matrix components. The selectivity herein is strongly achieved by using both the suitable mobile phase for separation and the fluorescence detector that can determine GFX without any suspicion from the interfering AMB which has no native fluorescence (Figure 2). Also, the recovery results of GFX-AMB synthetic mixture indicated the selectivity of the proposed method (Table 3).

Moreover, the selectivity of the method was extended to the ability to determine GFX in the presence of its degradation products without any interference.

Table 1. The accuracy and precision of the proposed method.

\begin{tabular}{ccccc}
\hline \multirow{2}{*}{$\begin{array}{c}\text { Conc. } \\
\text { (ng/band) }\end{array}$} & Recovery (\%) \pm SD $^{\mathbf{a}}$ & \multicolumn{2}{c}{ Intra-day precision } & \multicolumn{2}{c}{ Inter-day precision } \\
\cline { 3 - 5 } & $101.54 \pm 3.13$ & $98.17 \pm 2.56$ & \% RSD & Mean \pm SD $^{\mathbf{a}}$ \\
\hline 3 & $101.86 \pm 0.70$ & $99.79 \pm 2.66$ & 2.61 & $98.35 \pm 2.20$ \\
\% RSD $^{\mathbf{a}}$ & $99.11 \pm 0.44$ & $99.17 \pm 0.67$ & 0.67 & $98.25 \pm 1.87$ \\
180 & & & $98.80 \pm 1.47$ & 1.90 \\
\hline
\end{tabular}

${ }^{\mathrm{a}}$ Mean of six replicates.

Table 2. Robustness of the proposed HPTLC method.

\begin{tabular}{|c|c|}
\hline Experimental parameter variation & Recovery (\%) \pm SD $^{\mathrm{a}}$ \\
\hline No variation ${ }^{\mathrm{b}}$ & $100.23 \pm 1.93$ \\
\hline $\begin{array}{l}\text { - Ammonia concentration (\%) } \\
20 \\
30\end{array}$ & $\begin{array}{l}97.44 \pm 1.15 \\
98.50 \pm 0.76\end{array}$ \\
\hline $\begin{array}{l}\text { Mobile phase composition (v/v/v) } \\
\text { Ethyl acetate: methanol: } 25 \% \text { ammonia } \\
(7.5: 4.5: 3) \\
(\mathbf{8 . 5} 4.5: 3)\end{array}$ & $\begin{array}{c}99.14 \pm 2.22 \\
101.25 \pm 2.55\end{array}$ \\
\hline$(8: 4: 3)$ & $97.77 \pm 2.20$ \\
\hline$(8: 5: 3)$ & $99.33 \pm 1.64$ \\
\hline$(8: 4.5: 2.5)$ & $98.48 \pm 0.98$ \\
\hline$(8: 4.5: 3.5)$ & $102.45 \pm 0.56$ \\
\hline $\begin{array}{l}\text { - Saturation time (min) } \\
15 \\
25\end{array}$ & $\begin{array}{c}97.23 \pm 1.11 \\
101.67 \pm 1.55\end{array}$ \\
\hline
\end{tabular}

${ }^{\mathrm{a}}$ Mean of three determinations and drug concentration used $30 \mathrm{ng} / \mathrm{band}$; ${ }^{\mathrm{b}}$ Following the general assay procedure conditions. 
Table 3. Analysis of GFX in tablets by the proposed and reported methods.

\begin{tabular}{|c|c|c|}
\hline \multirow{2}{*}{ Dosage form } & \multicolumn{2}{|c|}{ Recovery \% \pm SD $(n=5)$} \\
\hline & Proposed method & Reported $^{\mathrm{b}}$ method (HPTLC) \\
\hline Factive $^{\circledR}$ tablets & $\begin{array}{c}99.51 \pm 1.05 \\
\mathrm{t}=0.45^{\mathrm{a}} \\
\mathrm{F}=4.15^{\mathrm{a}}\end{array}$ & $99.03 \pm 2.13$ \\
\hline Floxgaurd $^{\circledR}$ tablets & $\begin{array}{c}101.88 \pm 0.85 \\
t=0.40 \\
F=2.60\end{array}$ & $102.16 \pm 1.37$ \\
\hline Quinabiotic ${ }^{\circledR}$ tablets & $\begin{array}{c}98.48 \pm 1.82 \\
t=0.30 \\
F=1.58\end{array}$ & $98.16 \pm 1.45$ \\
\hline Gemique $^{\circledR}$ tablets & $\begin{array}{c}99.89 \pm 1.82 \\
t=1.76 \\
F=1.09\end{array}$ & $101.97 \pm 1.90$ \\
\hline Gemiloxes $^{\circledR}$ tablets & $\begin{array}{c}98.79 \pm 1.51 \\
t=1.39 \\
F=1.67\end{array}$ & $97.60 \pm 1.17$ \\
\hline Synthetic mixture with AMB & $\begin{array}{c}99.41 \pm 1.23 \\
t=0.17 \\
F=1.84\end{array}$ & $99.57 \pm 1.66$ \\
\hline
\end{tabular}

${ }^{\mathrm{a}}$ Theoretical values for $\mathrm{t}$ and $\mathrm{F}$ at $95 \%$ confidence limit and $\mathrm{n}=5$ were 2.31 and 6.39 , respectively; ${ }^{\mathrm{b}}$ Reference [11].

\subsection{Applications}

The proposed method was successfully applied for determination of GFX in its single dosage form tablets or in the synthetic mixture with AMB. Five replicate analyses were performed for each dosage form and the results obtained were validated by comparison with well-established reported method [11], by means of t-test and F-test at 95\% confidence level. No significant difference was found between the two methods, indicating the high accuracy and precision of the proposed HPTLC method (Table 3).

\subsection{Stability Indicating and Kinetics Studies}

ICH guidelines [1] suggested that the susceptibility to acid/base hydrolysis, oxidation, and photolytic stability are required tests and consequently the ideal stability indicating method is one that quantifies the drug alone and also resolves its degradation products. Therefore, GFX was subjected to different stress conditions according to ICH recommended guidelines. The results suggested the following degradation behavior:

\subsubsection{Acidic Degradation}

Initially, 0.5 M HCl was used at room temperature for degradation of GFX at different time intervals but mild degradation was observed after $4 \mathrm{hr}$. Thus, the strength of acid was increased to $1 \mathrm{M} \mathrm{HCl}$ where $95.82 \%$ of GFX was remained after $1 \mathrm{hr}$. Then, the concentration of GFX was decreased gradually with time to be $11.27 \%$ after $12 \mathrm{hr}$. The developed densitogram of the degraded GFX showed well separated peak of GFX with two additional peaks at different $\mathrm{R}_{\mathrm{f}}$ values.

It may be noteworthy that this method is not suggested to establish material balance between the extent of drug decomposition and formation of the degradation products. This may be due to that some of the products are shown to decompose further in a complex reaction scheme. Where, one peak of an acid degradation product (D1) was observed after $1 \mathrm{hr}$ at $\mathrm{R}_{\mathrm{f}} \mathbf{0 . 2 5}$. Then, $\mathrm{D} 1$ was decreased gradually with time with the appearance of another degradant (D2) at $\mathrm{R}_{\mathrm{f}} 0.13$ (Figure 3(a) and Figure 3(b)). So, the acidic degradation behavior may be expressed as follow:

$$
\mathrm{GFX} \rightarrow \mathrm{D} 1 \rightarrow \mathrm{D} 2
$$

The kinetics of acidic degradation was also studied, through the decrease in drug concentration with time. Figure 4 indicates that the degradation process of GFX can be described by first-order reaction kinetic. From the slope of the straight line, $\mathrm{k}$, and $\mathrm{t} 1 / 2$ were calculated as $0.194 \mathrm{hr}^{-1}$ and $3.564 \mathrm{hr}$, respectively. 


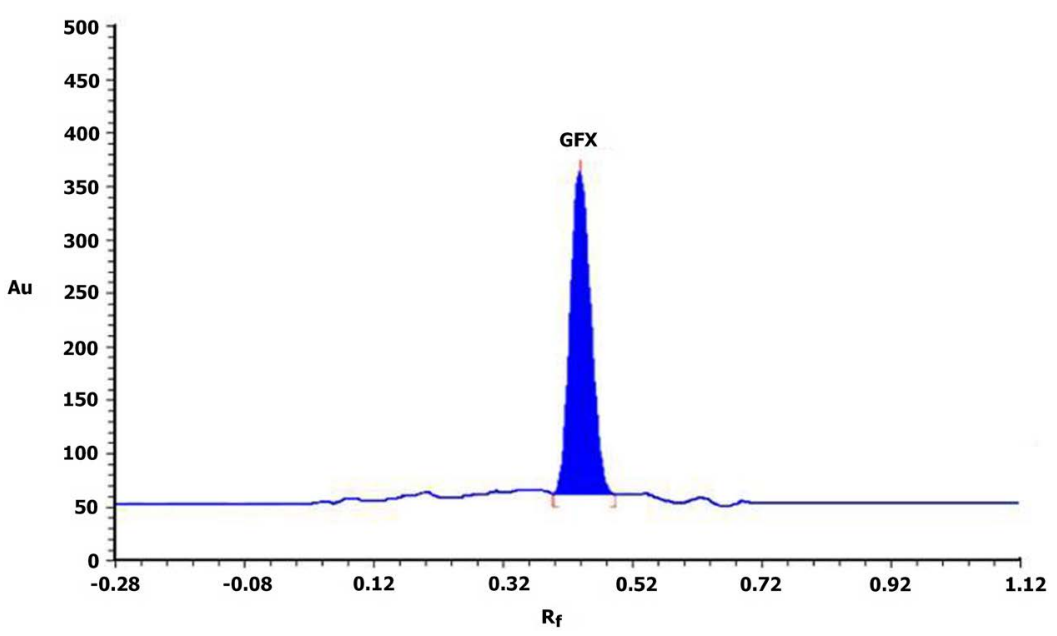

(a)

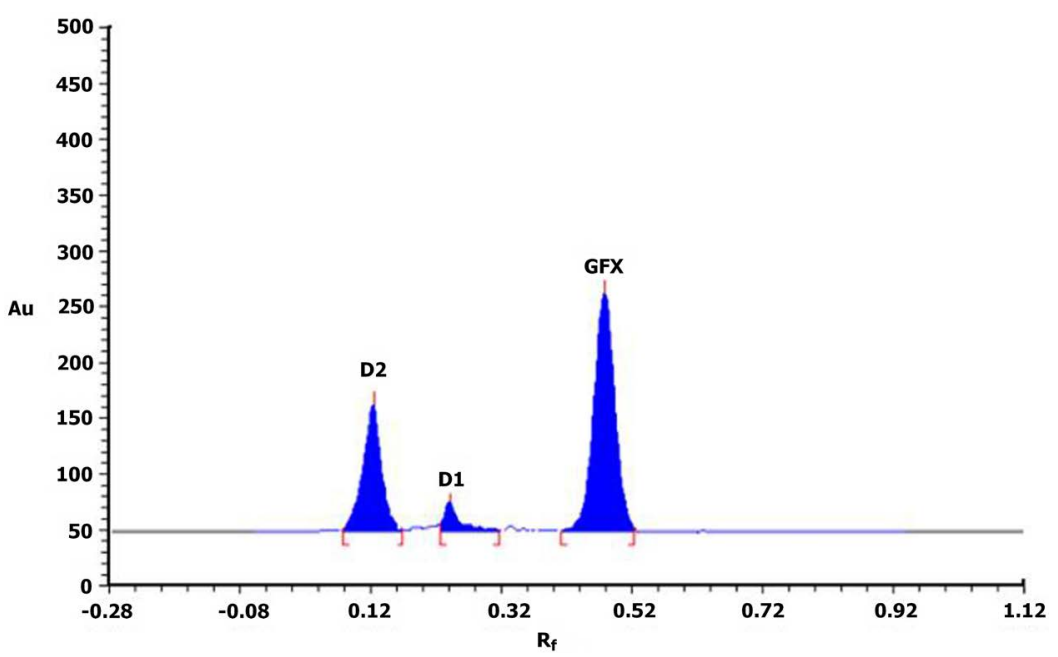

(b)

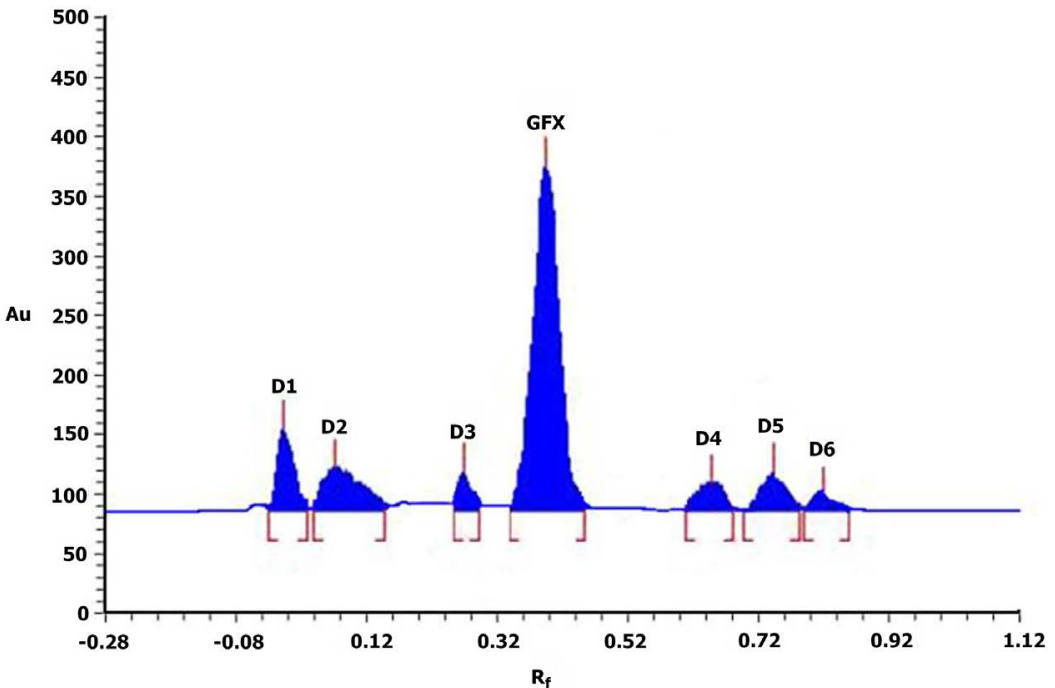

(c)

Figure 3. HPTLC densitograms of GFX (150 ng/band) at different stress conditions. (a) Pure GFX ( $\left.\mathrm{R}_{\mathrm{f}} 0.47 \pm 0.03\right)$; (b) Acidic; and (c) Photo-degradation conditions. 


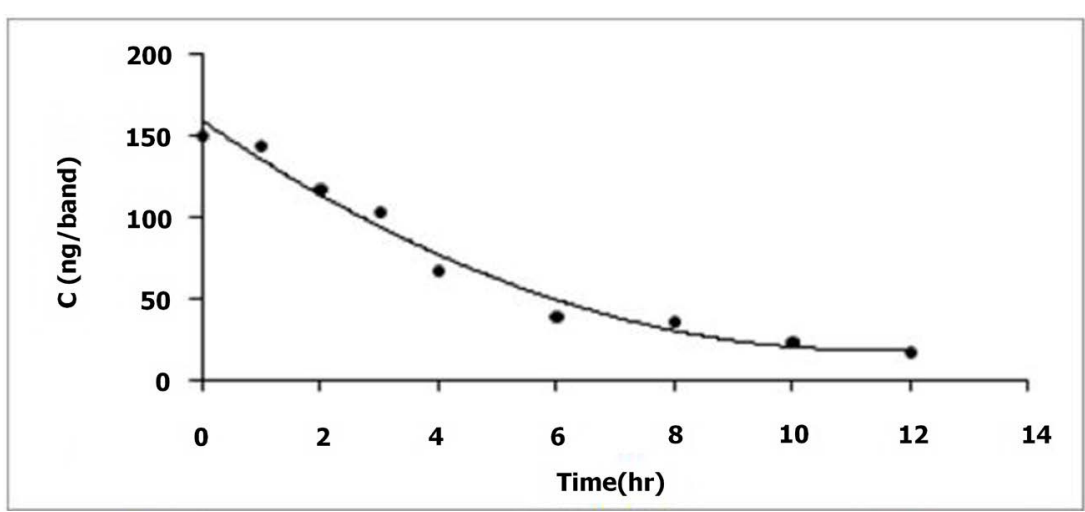

(a)

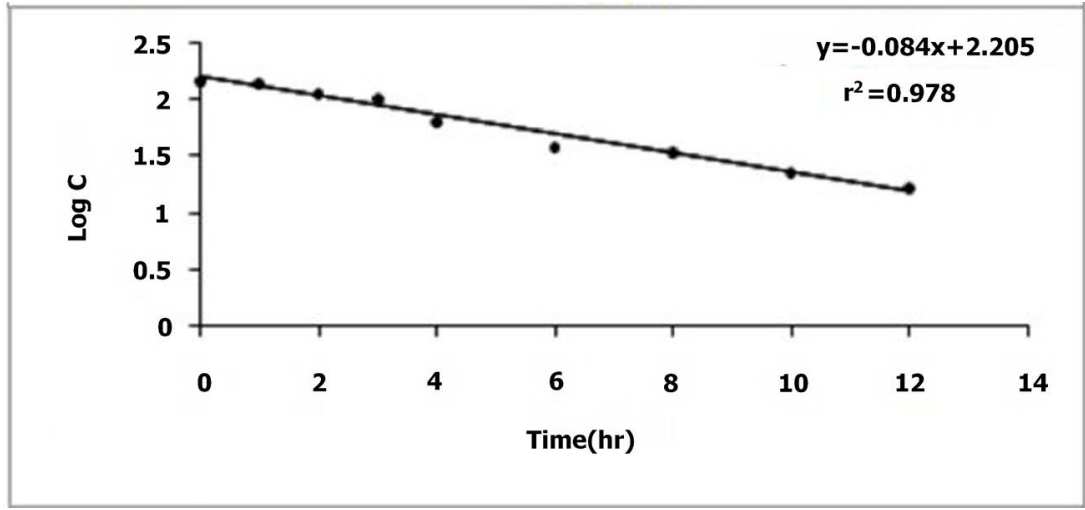

(b)

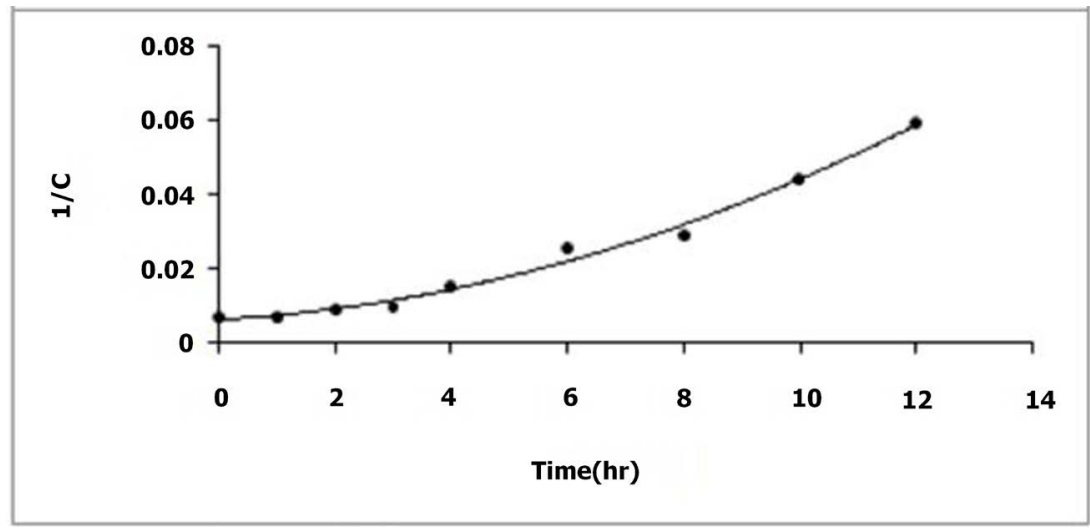

(c)

Figure 4. The kinetics of acidic degradation of GFX. (a) Plot of the remaining concentration (C, ng/band) of GFX versus time (hr); (b) Plot of log C versus time (hr); and (c) Plot of $1 / \mathrm{C}$ versus time (hr).

\subsubsection{Alkaline Degradation}

The degradation rate of GFX in alkali was very fast as compared to that in acid. Where, complete alkaline degradation of GFX was observed at once by using $1 \mathrm{M} \mathrm{NaOH}$. Also, the alkaline degradation of GFX in $0.5 \mathrm{M}$ $\mathrm{NaOH}$ was so fast that about $80 \%$ was degraded after $30 \mathrm{~min}$. Then, the study was investigated in $0.2 \mathrm{M} \mathrm{NaOH}$ at room temperature, where $73.91 \%$ of GFX was still remained after $1 \mathrm{hr}$ then complete drug degradation was observed after $8 \mathrm{hr}$.

It is notable that there is gradual decrease in the peak area of GFX with increasing time but without corresponding appearance of a new peak. This indicates that the drug is hydrolysed under alkaline conditions but non- 
fluorescent degradants were performed. Therefore, the alkaline degradation behavior may be expressed as follow:

\section{GFX $\rightarrow$ D1}

Studying the kinetics of alkaline degradation of GFX indicated that the alkaline degradation of GFX can be described by the first-order kinetic. Then, $\mathrm{k}$ and $\mathrm{t}_{1 / 2}$ were calculated as $0.370 \mathrm{hr}^{-1}$ and $1.873 \mathrm{hr}$, respectively.

\subsubsection{Oxidative Degradation}

Initial studies were used $3 \% \mathrm{H}_{2} \mathrm{O}_{2}$ at room temperature for $6 \mathrm{hr}$. No degradation was observed at all at this concentration. Thereafter, the drug was exposed to $30 \% \mathrm{H}_{2} \mathrm{O}_{2}$ at room temperature for a period of $10 \mathrm{hr}$. GFX was found to be nearly stable to the oxidative degradation till $2 \mathrm{hr}$ then mild degradation was observed. Finally, after $10 \mathrm{hr}, 72.98 \%$ of GFX was still remained with no appearance of any extra peaks.

The oxidative degradation kinetics was evaluated by determination of the regression coefficients. The obtained regression coefficient values were $-0.9646,-0.9552$ and 0.9440 for zero, first and second order kinetics, respectively. Therefore, the oxidative degradation of GFX could be better described as zero order kinetic. The obtained degradation rate constant $(\mathrm{k})$ and $\mathrm{t}_{1 / 2}$ were: $4.036 \mathrm{ng} \mathrm{hr}^{-1}$ and $18.581 \mathrm{hr}$, respectively.

\subsubsection{Neutral Hydrolysis}

Initial studies were performed by heating aqueous solution of GFX at $40^{\circ} \mathrm{C}$ or $75^{\circ} \mathrm{C}$ for $6 \mathrm{hr}$. No degradation was observed under these conditions. Thereafter, the drug solution was heated at $100^{\circ} \mathrm{C}$ for $12 \mathrm{hr}$. Mild degradation was observed after $2 \mathrm{hr}$ and nearly 15\% of GFX was degraded after $12 \mathrm{hr}$ without appearance of extra peaks.

The degradation kinetics of GFX under the neutral hydrolysis was evaluated by determination of the regression coefficients of the three plots which were found to be $-0.9619,-0.9651$ and 0.9682 for zero, first and second order plot; respectively. These results showed that the neutral hydrolysis of GFX could be better described as second order kinetic. The calculated $\mathrm{k}$ and $\mathrm{t}_{1 / 2}$ were $9.147 \times 10^{-5} \mathrm{ng}^{-1} \cdot \mathrm{hr}^{-1}$ and $72.883 \mathrm{hr}$, respectively.

\subsubsection{Photo-Degradation}

Phototoxicity is a class effect, common to all the fluoroquinolones. It appears as a result of the interaction between UVA light (320 - $400 \mathrm{~nm}$ ) and the fluoroquinolone molecule. This interaction produces photo-degradation products and/or reactive oxygen species that may result in tissue damage [23]. Therefore, the purpose of photostability testing is to provide evidence on how the quality of a drug varies with time under the influence of light. A wavelength of $365 \mathrm{~nm}$ was selected herein according to reported study for GFX on the skin [24].

The results ensured the photo-degradation of GFX at $365 \mathrm{~nm}$ with formation of yellow-colored solutions which increased along the exposure time. The peak area of GFX showed considerable decrease over time and nearly $15.10 \%$ of the drug was still remained after $8 \mathrm{hr}$. The photo-degradation pattern of GFX shows 6 wellseparated photo-degradation products (named according to increased $\mathrm{R}_{\mathrm{f}}$ values; D1-D6) (Figure 3(c)). Actually, the behavior of GFX showed a complex reaction scheme where, some products are shown to decompose further to other ones.

GFX photo-degradation kinetics can be described by first-order reaction kinetic. The calculated $k$ and $t_{1 / 2}$ were $0.214 \mathrm{hr}^{-1}$ and $3.235 \mathrm{hr}$, respectively. These results come in concordance with the photo-degradation pattern of other fluoroquinolones those exposed to UVA and determined using HPTLC technique [25].

\subsection{Stability of Standard Solution of GFX}

This study is concerned with the recommended conditions at which the drug can be exposed for a stipulated period of time and retains its stability. This is critical step for any drug to avoid the frequent errors in the quantitative analysis. Therefore, the stability of methanolic solution of GFX was tested for $144 \mathrm{hr}$, under different storage conditions. The results revealed that GFX was considered stable when stored at refrigerator and at room temperature with protection from light (Figure 5).

Unlike the above mentioned storage conditions, degradation products related to GFX were detected for the unprotected solutions and that exposed to direct daylight. In both cases, the concentration of GFX decreased during storage with the appearance of degradation products (Figure 4). It was notable that, the least stable solutions are those exposed to direct daylight which begins to be degraded significantly from the first day exposure and completely disappeared within $96 \mathrm{hr}$. While, the other solution that stored without protection from light was 
degraded gradually with time and nearly $27.85 \%$ of GFX was still remained after $144 \mathrm{hr}$. Thus, to preserve GFX solution from degradation, protection from light is critical.

The kinetics of GFX can be described by zero order kinetic for unprotected solutions where, the degradation rate constant $(\mathrm{k})$ and $\mathrm{t}_{1 / 2}$ were calculated as $0.746 \mathrm{ng}^{-\mathrm{hr}^{-1}}$ and $100.48 \mathrm{hr}$, respectively. While, the solutions exposed to daylight can be expressed by first-order kinetic where, $\mathrm{k}$ and $\mathrm{t}_{1 / 2}$ were $0.055 \mathrm{hr}^{-1}$ and $12.61 \mathrm{hr}$, respectively (Figure 6).

Noteworthy, the photo-degradation rate of GFX was higher after exposure to artificial UV light than that under daylight condition. This may be due to that, the proportion of photo-degradation may be dependent on the intensity and wavelength of radiation where the true environmental UVA exposure varies with time of day, pollution and its position to the window glass [24]. Moreover, the type of container may play a role where the ordinary glass (used in direct daylight effect) is partially transparent to UVA but quartz cell (used in UV effect at $365 \mathrm{~nm}$ ) is highly transparent [26].

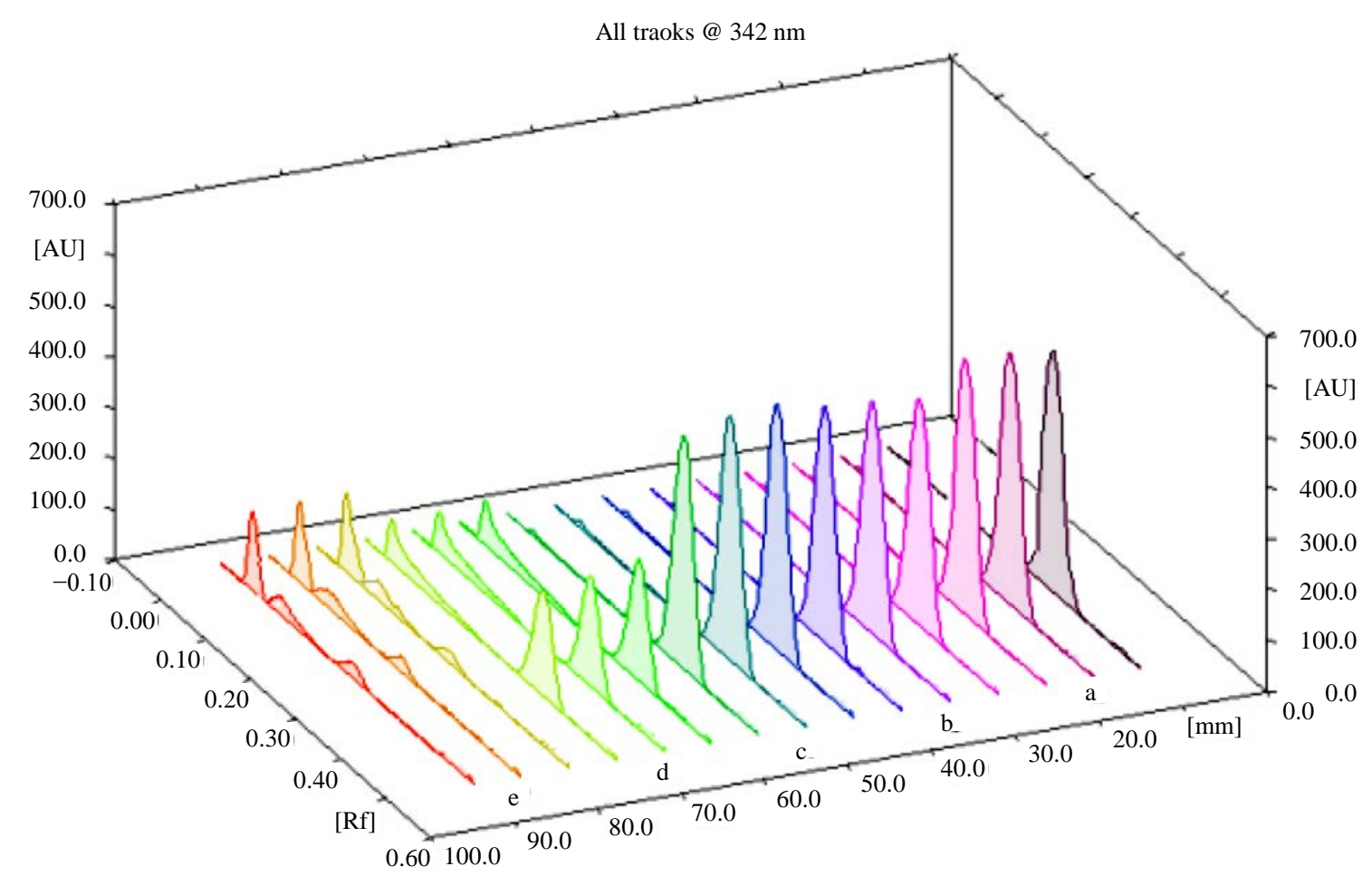

Figure 5. 3D HPTLC-densitogram indicating the effect of different storage conditions on GFX (150 ng/band) after 144 hr: (a) Fresh solution; (b) Refrigerated solution; (c) Protected solution at room temperature; (d) Unprotected solution at room temperature; and (e) Solution exposed to direct daylight.

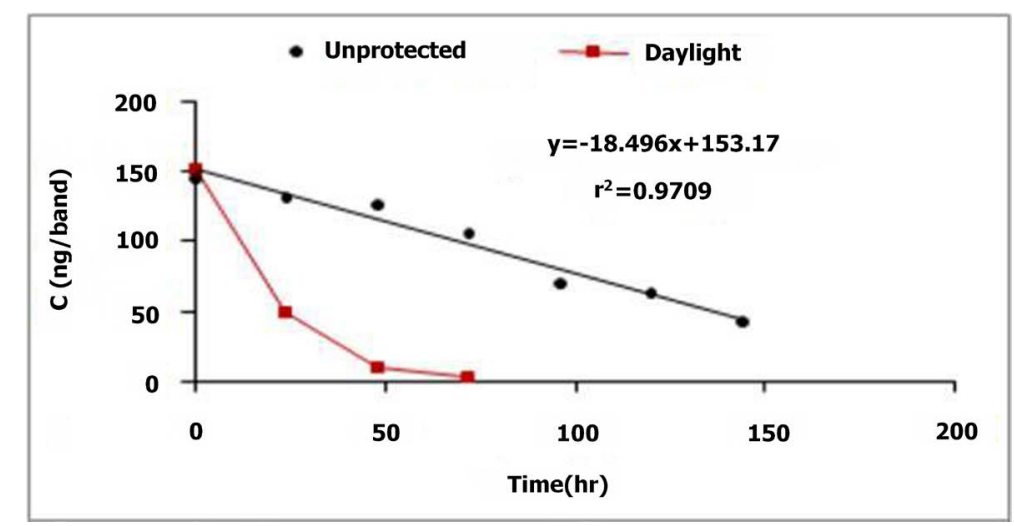

(a) 


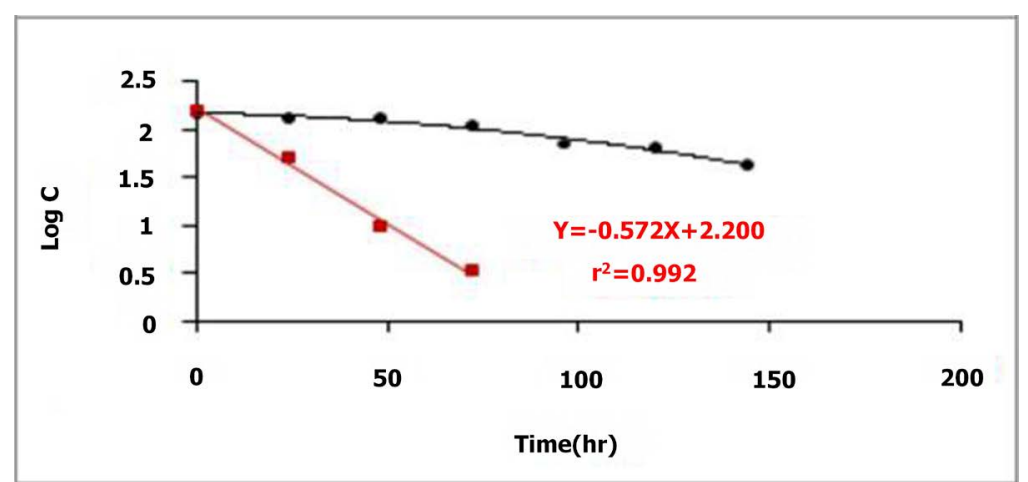

(b)

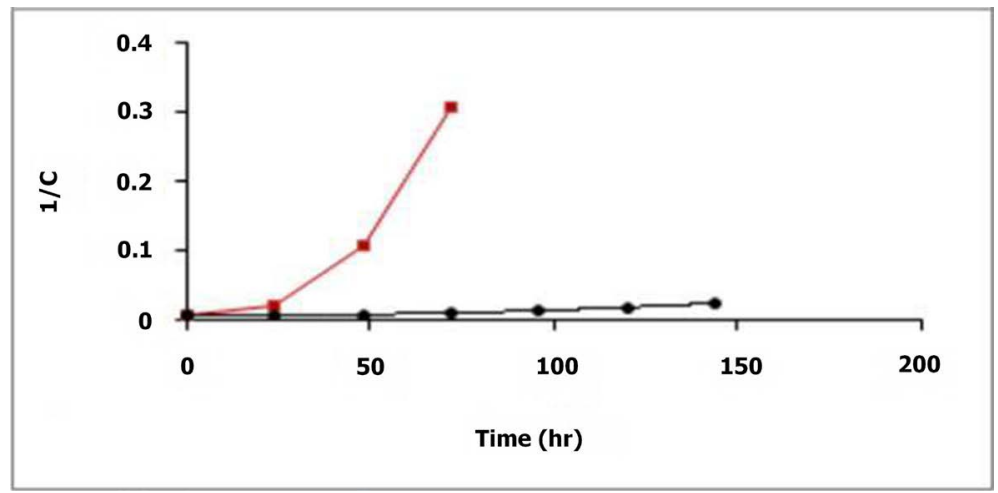

(c)

Figure 6. The kinetics of GFX hydrolysis at different storage conditions: (a) Plot of the remaining concentration (C, ng/band) of GFX versus time (hr); (b) Plot of $\log \mathrm{C}$ versus time (hr); and (c) Plot of $1 / \mathrm{C}$ versus time (hr).

\section{Conclusion}

This work described simple, sensitive, and selective stability-indicating HPTLC assay with fluorescence detection for determination of GFX. Statistical analysis proves that the proposed method is suitable for the analysis of GFX in its single and combined dosage forms. Moreover, it was tested and validated as stability-indicating assay for determination of GFX in presence of its degradation products. It is found to be more easy, economic and less time-consuming as compared with the reported HPLC and LC-MS methods with stability-indicating property. Furthermore, it is effectively applied to study the kinetics of the degradation behavior of GFX at different stress conditions for the first time. It also provides a good pathway for the best storage conditions that can preserve GFX stable for more reproducible results. Therefore, this method is worthy recommended for routine quality control of GFX in pharmaceutical industries and research laboratories.

\section{References}

[1] ICH Guidance for Industry (Q1A) (R2) (2003) Stability Testing of New Drug Substances and Products in Federal Register. ICH Guidance for Industry, Geneva.

[2] El Zeany, B.A., Moustafa, A.A. and Farid, N.F. (2003) Determination of Zolpidem Hemitartrate by Quantitative HPTLC and LC. Journal of Pharmaceutical and Biomedical Analysis, 33, 393-401. http://dx.doi.org/10.1016/S0731-7085(03)00243-7

[3] Guermouche, M.H., Habel, D. and Guermouche, S. (1999) Assay of Tinidazole in Human Serum by High-Performance Thin-Layer Chromatography: Comparison with High-Performance Liquid Chromatography. Journal of AOAC International, 82, 244-247.

[4] Kaale, E., Risha, P. and Layloff, T. (2011) TLC for Pharmaceutical Analysis in Resource Limited Countries. Journal of Chromatography A, 1218, 2732-2736. http://dx.doi.org/10.1016/j.chroma.2010.12.022

[5] Le, T.P. and Xiong, Y.Q. (2001) Gemifloxacin. Drugs of Today, 37, 401-410. 
http://dx.doi.org/10.1358/dot.2001.37.6.627959

[6] Yoo, B.K., Triller, D.M., Yong, C.S. and Lodise, T.P. (2004) Gemifloxacin: A New Fluoroquinolone Approved for Treatment of Respiratory Infections. The Annals of Pharmacotherapy, 38, 1226-1235. http://dx.doi.org/10.1345/aph.1E003

[7] Hong, C.Y. (2001) Discovery of Gemifloxacin (Factive, LB20304a): A Quinolone of New a Generation. Il Farmaco, 56, 41-44. http://dx.doi.org/10.1016/S0014-827X(01)01017-5

[8] Atia, N.N., Mahmoud, A.M., El-Shabouri, S.R. and El-Koussi, W.M. (2013) Two Validated Spectrofluorometric Methods for Determination of Gemifloxacin Mesylate in Tablets and Human Plasma. International Journal of Analytical Chemistry, 2013, 1-11. http://dx.doi.org/10.1155/2013/137279

[9] Doyle, E., Fowles, S.E., McDonnell, D.F., McCarthy, R. and White, S.A. (2000) Rapid Determination of Gemifloxacin in Human Plasma by High-Performance Liquid Chromatography-Tandem Mass Spectrometry. Journal of Chromatography B: Biomedical Sciences and Applications, 746, 191-198. http://dx.doi.org/10.1016/S0378-4347(00)00333-9

[10] Al-Hadiya, B.M.H., Khady, A.A. and Mostafa, G.A.E. (2010) Validated Liquid Chromatographic-Fluorescence Method for the Quantitation of Gemifloxacin in Human Plasma. Talanta, 83, 110-116. http://dx.doi.org/10.1016/j.talanta.2010.08.047

[11] Rote, A.R. and Pingle, S.P. (2009) Reverse Phase-HPLC and HPTLC Methods for Determination of Gemifloxacin Mesylate in Human Plasma. Journal of Chromatography B, 877, 3719-3723. http://dx.doi.org/10.1016/j.jchromb.2009.08.013

[12] El-Koussi, W.M., Atia, N.N., Mahmoud, A.M. and El-Shabouri, S.R. (2014) HPTLC Method for Direct Determination of Gemifloxacin Mesylate in Human Plasma. Journal of Chromatography B, 967, 98-101. http://dx.doi.org/10.1016/j.jchromb.2014.07.004

[13] Raja, T. and Rao, A.L. (2012) Development and Validation of HPTLC Method for the Simultaneous Estimation of Gemifloxacin Mesylate and Ambroxol Hydrochloride in Bulk and Tablet Dosage Form. Analytical Chemistry Letters, 2, 152-158. http://dx.doi.org/10.1080/22297928.2000.10648263

[14] Elbashir, A., Saad, B., Ali, A.S.M., Al-Azzam, K. and Aboul-Enein, H. (2008) Validated Stability Indicating Assay of Gemifloxacin and Lomefloxacin in Tablet Formulations by Capillary Electrophoresis. Journal of Liquid Chromatography \& Related Technologies, 31, 1465-1477. http://dx.doi.org/10.1080/10826070802039481

[15] Ranjane, P.N., Gandhi, S.V., Kadukar, S.S. and Bothara, K.G. (2010) Stability Indicating RP-LC Method for the Determination of Gemifloxacin Mesylate. Chromatographia, 71, 1113-1117. http://dx.doi.org/10.1365/s10337-009-1351-1

[16] Gandhimathi, N., Ravi, T.K. and Bharathi, N. (2010) Study of Hydrolytic and Oxidative Behavior of Gemifloxacin Mesylate in Aqueous Solution by LC-MS. Journal of Global Pharma Technology, 2, 81-85.

[17] Paim, C.S., Führ, F., Barth, A.B., Goncalves, C.E.I., Nardi, N., Steppe, M. and Schapoval, E.E.S. (2011) Gemifloxacin Mesylate Stability Evaluation Applying a Validated Bioassay Method and in Vitro Cytotoxic Study. Talanta, 83, 17741779. http://dx.doi.org/10.1016/j.talanta.2010.11.069

[18] Nageswara Rao, R., Naidu, C.G., Prasad, K.G. and Narasimha, R. (2011) Development and Validation of a RP-HPLC Method for Stability-Indicating Assay of Gemifloxacin Mesylate Including Identification of Related Substances by LC-ESI-MS/MS, ${ }^{1} \mathrm{H}$ and ${ }^{13} \mathrm{C}$ NMR Spectroscopy. Biomedical Chromatography, 25, 1222-1229. http://dx.doi.org/10.1002/bmc.1594

[19] Paim, S., Fuhr, F., Miron, S., Pereira, L., Malesuik, D., Steppe, M. and Schapoval, E.S. (2010) Stability-Indicating LC Assay and Determination of System Suitability Limits with a Robustness Test of Gemifloxacin Mesylate in Tablets. Current Analytical Chemistry, 6, 269-276.

[20] Fried, B. and Sherma, J. (1999) Thin-Layer Chromatography. Vol. 81, CRC Press, Boca Raton.

[21] Fried, B. and Sherma, J. (1982) Thin Layer Chromatography. Vol. 17, Marcel Dekker, Inc., New York, 308.

[22] ICH Guidance for Industry, Q2 (R1) (2005) Validation of Analytical Procedures: Text and Methodology. Federal Register, Geneva, 1-13.

[23] Wainwright, N., Collins, P. and Ferguson, J. (1993) Photosensitivity Associated with Antibacterial Agents. Drug Safety, 9, 437-440. http://dx.doi.org/10.2165/00002018-199309060-00006

[24] Vousden, M., Ferguson, J., Richards, J., Bird, N. and Allen, A. (1999) Evaluation of Phototoxic Potential of Gemifloxacin in Healthy Volunteers Compared with Ciprofloxacin. Chemotherapy, 45, 512-520. http://dx.doi.org/10.1159/000007246

[25] Hidalgo, M.E., Pessoa, C., Fernandez, E. and Cardenas, A.M. (1993) Comparative Determination of Photodegradation Kinetics of Quinolones. Journal of Photochemistry and Photobiology A: Chemistry, 73, 135-138. http://dx.doi.org/10.1016/1010-6030(93)80042-8

[26] Endruweit, A., Johnson, M.S. and Long, A.C. (2006) Curing of Composite Components by Ultraviolet Radiation: A Review. Polymer Composites, 27, 119-128. http://dx.doi.org/10.1002/pc.20166 
Scientific Research Publishing (SCIRP) is one of the largest Open Access journal publishers. It is currently publishing more than 200 open access, online, peer-reviewed journals covering a wide range of academic disciplines. SCIRP serves the worldwide academic communities and contributes to the progress and application of science with its publication.

Other selected journals from SCIRP are listed as below. Submit your manuscript to us via either submit@scirp.org or Online Submission Portal.
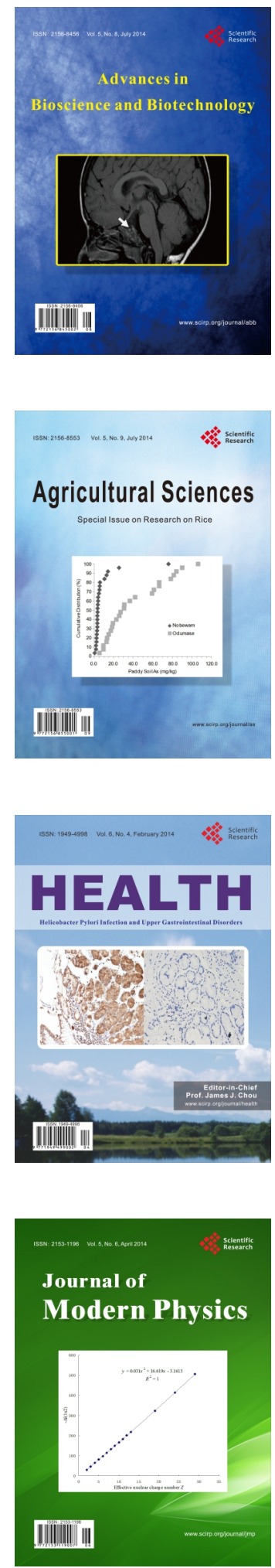
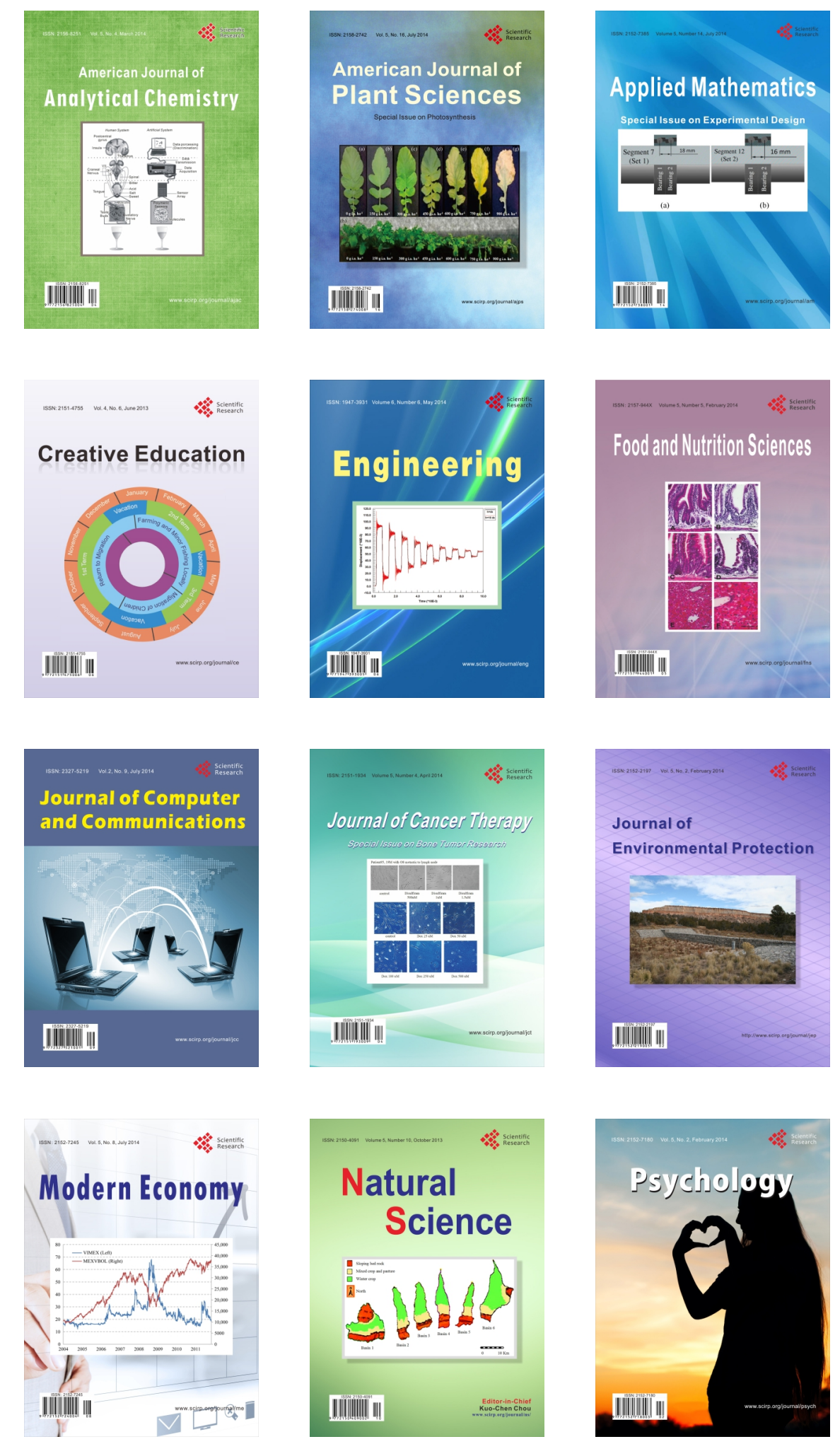